\title{
Seasonal Cointegration Approach on Expenditure Based Gross Domestic Product and Its Some Sub-Components for Turkey
}

\author{
Prof. Dr. Mehmet Özmen (Çukurova University, Turkey) \\ Ph.D. Candidate Sera Şanlı (Çukurova University, Turkey)
}

\begin{abstract}
In this study, it has been aimed to investigate the existence of co-integration relationship between quarterly gross domestic product (GDP), final consumption expenditures of resident households (CONS), exports of goods and services (EXP), government final consumption expenditures (GOV) and private sector machinery-equipment (PRIEQ) series for the period 1998Q1-2014Q4 for Turkey. Since, Engle and Granger (1987) cointegration test does not take unit roots at seasonal frequencies into account; seasonal cointegration approach proposed by Engle, Granger, Hylleberg and Lee (EGHL) (1993) has been conducted in order to be able to detect the long-run equilibrium relationship among variables which are integrated at the same seasonal frequency. With the aim of determining the stationarity order of series, HEGY seasonal unit root test has been applied. Consequently, there has been found a cointegrating relationship only between GDP and GOV series at quarterly frequencies for only the auxiliary regression including constant term and seasonal dummies.
\end{abstract}

\section{Introduction}

All the studies regarding time series methods are useful only in case the series in interest do not display seasonal patterns. That is why it is of great importance to take the time series properties of the series like seasonal patterns or trends into account while dealing with economic time series data. The analyses of seasonal unit roots are generally conducted with the most popular approach developed by Hylleberg, Engle, Granger and Yoo (1990) called HEGY by working with different models that include trends, constants and seasonal dummy variables.

Cointegrated series are series which are non-stationary alone but stationary in their linear combinations. The concept of seasonal cointegration is valid for models including stochastic seasonals just as the concept of cointegration showing itself in models including stochastic trends (Maddala and Kim, 1998). One advantage of HEGY test procedure is that it enables to test for unit roots at each frequency separately. So, concerning quarterly data including the four roots which are 1, $-1, \pm i$; Engle, Granger, Hylleberg and Lee (1993) propose different levels of seasonal cointegration. In conclusion, cointegration relationship will be analyzed at frequencies in which series are all integrated at the same order. For each frequency, separate cointegration tests are applied. Through seasonal cointegration analysis, whether the variables that are integrated at the same seasonal frequency have a stationary relationship in time is investigated. However, in cointegration test proposed by Engle and Granger (1987), unit roots at seasonal frequencies are not taken into consideration. In this case, if the presence of seasonal unit roots in series is ignored; the parameter in interest will not be estimated in a consistent way. For this reason, it is more appropriate to conduct seasonal cointegration analysis (Caglayan, 2003) (Ayvaz Kiz1lgol, 2011).

As associated with the unit root concept, the relationship between cointegration and error correction models was first suggested by Granger (1981) and then it was also introduced by Granger and Weiss (1983). Engle and Granger (1987) also offer a theorem based on Granger (1983) which associates the moving average (MA), autoregressive (AR) and error correction representations for cointegrated systems and estimation methods. Engle, Granger and Hallman (1989) and Hylleberg, et al. (1990) introduce the concept of seasonal cointegration in their papers. Kunst (1993) tries to evaluate the effects of modelling seasonal cointegration on predictive accuracy for German and United Kingdom (U.K.) macroeconomic series.

HEGY seasonal unit root test has originally been derived for quarterly seasonality and extended to data with different frequencies. Contrary to the DHF test proposed by Dickey, Hasza and Fuller (1984), HEGY procedure enables to test for unit roots at each seasonal frequency as well as the zero frequency separately and the techniques are applied to quarterly U.K. data for the period 1955:1 to 1984:4 in order to examine the cointegration relationship between consumption and income variables at different frequencies. As a result of application, Hylleberg et al. (1990) find the unit elasticity error correction model to be invalid at any frequency. The asymptotic distributions of the t-statistics from their testable model have been analyzed by Chan and Wei (1988). In their paper, Chan and Wei (1988) characterize the limiting distributions of the least square estimates as a functional of stochastic integrals.

In their paper, Kunst and Franses (1998) deal with the impact of deleting, restricting or not restricting seasonal constants on forecasting seasonally cointegrated time series for Austria, Germany and the U.K.

In their paper, Hamori and Tokihisa (2001) analyze the stability of Japanese money demand function using seasonal integration and seasonal cointegration and they find that there exist unit roots in money balances, interest rates and real gross domestic product (GDP) series in different cycles. Because of the rejection of seasonal 
cointegration in every case, it is also expressed that there is no stable relationship between money supply and the real economy for the period under consideration.

In the study by Lof and Lyhagen (2002), the comparison of the forecasting performance of the seasonally cointegrated model of Johansen and Schaumburg (1999) and of the specification proposed by Lee (1992) with a parameter restriction included at the annual frequency has been covered. For three data sets from Austria, Germany and U.K., each including six variables: GDP, private consumption, gross fixed investment, goods exports, real wages and the real interest rate; it is also dealt with how the inclusion of restricted or unrestricted seasonal dummies may have an influence in the seasonal cointegration models. Since the semi-annual frequency for Austria appears to have full rank and the U.K. data set shows a rather weak cointegration evidence at the seasonal frequencies, only the German data are used in the forecasting example. Through Monte Carlo study, Lof and Lyhagen (2002) have found some evidence that for the smaller sample sizes the specification of Johansen and Schaumburg (1999) may result in worse forecasts in the case of the inclusion of more cointegrating relations and for larger sample sizes the study results have been found to favour of this specification.

In her paper, Caglayan (2003) investigates the presence of seasonal unit root for the monthly series of personal consumption expenditures made to non-durable and semi-durable goods and services, per capita disposable income and stock market returns that are concerned with the life-long permanent income hypothesis over the period 1988:01-2000:04 and examines if cointegration exists among given variables by using HEGY procedure. In her study, the presence of seasonal unit root has been found in consumption expenditures and disposable income series for both 0 and $1 / 4$ frequencies and in stock market returns series for $1 / 4$ frequency. Also, it is concluded that consumption expenditures and disposable income variables are cointegrated at zero frequency.

In her study, Ayvaz Kızılgöl (2011) has examined if GDP, export, consumption and investment series have seasonal unit roots and display a seasonal cointegration relationship by using quarterly series for the period 1987Q1-2007Q3 and through Engle, Granger, Hylleberg and Lee (1993) tests, she concluded that there is no seasonal cointegration relationship between series at zero and biannual frequencies. However, a seasonal cointegration relationship has been detected between gross domestic product and consumption series at $1 / 4$ (and $3 / 4$ frequency) for the model with intercept and seasonal dummy variables.

Mert and Demir (2014) have aimed to examine the seasonal patterns to detect if seasonal cointegration relationship exists between export and import series over the 1969:1-2014:1 quarterly periods. Two series have been found to be cointegrated at $1 / 4$ and $3 / 4$ frequencies with one cointegrating vector and not cointegrated at zero (long-run) frequency. The results have shown that error correction mechanism works at $1 / 4$ frequency. However, at $3 / 4$ frequency, because of the error correction term is positive signed contrast to the expectations, the error correction mechanism has been determined not to operate.

In this study, it has been aimed to investigate the existence of co-integration relationship between quarterly gross domestic product (GDP), final consumption expenditures of resident households (CONS), exports of goods and services (EXP), government final consumption expenditures (GOV) and private sector machinery-equipment (PRIEQ) series for the period 1998Q1-2014Q4. The rest of this paper has been organized as follows: Section 2 considers the theoretical approach for seasonal cointegration with single and multiple equations; Section 3 provides the information about the data set and application. Finally, Section 4 presents the brief conclusions.

\section{Theoretical Approach for Seasonal Cointegration}

The concept of seasonal cointegration is valid for models including stochastic seasonals just as the concept of cointegration showing itself in models including stochastic trends (Maddala and Kim, 1998). One advantage of HEGY test procedure is that it enables to test for unit roots at each frequency separately. So, concerning quarterly data including the four roots which are 1, $-1, \pm i$; Engle et al. (1993) propose different levels of seasonal cointegration. Assume that $y_{t}$ and $z_{t}$ series are seasonally cointegrated so that $\Delta_{4} y_{t}$ and $\Delta_{4} z_{t}$ are stationary. When these two series have a common non-seasonal unit root (that is, they are cointegrated at long-run zero frequency - at root 1), we have the error term

$$
u_{t}=\left(1+L+L^{2}+L^{3}\right) y_{t}-\alpha_{1}\left(1+L+L^{2}+L^{3}\right) z_{t}
$$

which is stationary. If seasonal cointegration exists at frequency $1 / 2$ corresponding to unit root -1 , we have

$$
v_{t}=\left(1-L+L^{2}-L^{3}\right) y_{t}-\alpha_{2}\left(1-L+L^{2}-L^{3}\right) z_{t}
$$

which is stationary (so, it does not require $(1+L)$ filter to be stationary) and finally if seasonal cointegration exists at frequency $1 / 4$ corresponding to unit roots $\pm i$ and $\left(1-L^{2}\right)$ filter we have

$$
w_{t}=\left(1-L^{2}\right) y_{t}-\alpha_{3}\left(1-L^{2}\right) z_{t}-\alpha_{4}\left(1-L^{2}\right) y_{t-1}-\alpha_{5}\left(1-L^{2}\right) z_{t-1}
$$


is stationary. In case all three series $u_{t}, v_{t}$ and $w_{t}$ are stationary, the seasonal cointegration model is represented in a simple form as

$$
\begin{aligned}
& \Delta_{4} y_{t}=\beta_{11} u_{t-1}+\beta_{21} v_{t-1}+\beta_{31} w_{t-2}+\beta_{41} w_{t-3}+\varepsilon_{1 t} \\
& \Delta_{4} z_{t}=\beta_{21} u_{t-1}+\beta_{22} v_{t-1}+\beta_{32} w_{t-2}+\beta_{42} w_{t-3}+\varepsilon_{2 t}
\end{aligned}
$$

where $\beta$ s represent the error correction terms. In addition; constant, seasonal dummies and trend variables can be incorporated into these equations. This method with two-step proposed by Engle et al. (1993) is similar to the Engle-Granger approach applied for nonseasonal time series: in the first step, equations (1) to (3) are estimated by ordinary least squares (OLS) procedure and in the second step 'Augmented Dickey Fuller' (ADF) unit root tests are applied to $\hat{u}_{t}, \hat{v}_{t}$ and $\hat{w}_{t}$ (in other words, this transaction allows us to check if estimated residuals $\hat{u}_{t}$ to $\hat{w}_{t}$ are stationary). The tests for $\hat{u}_{t}$ and $\hat{v}_{t}$ have the same critical values as those in Engle and Granger (1987). However, critical values for testing $\hat{w}_{t}$ are different. For this case, the critical values are tabulated in Engle et al. (1993) (Maddala and Kim, 1998).

As mentioned above, subsequent to estimating $\alpha_{1}$ to $\alpha_{5}$ by OLS for bivariate time series involving $y_{t}$ and $z_{t}$, the stationarity condition is checked for estimated residuals $\hat{u}_{t}$ to $\hat{w}_{t}$. This is executed by using the following auxiliary regressions:

$$
\begin{aligned}
& (1-L) \hat{u}_{t}=\pi_{1} \hat{u}_{t-1}+\sum_{i=1}^{l_{1}} \gamma_{i}(1-L) \hat{u}_{t-i}+\varepsilon_{t} \\
& (1+L) \hat{v}_{t}=\pi_{2}\left(-\hat{v}_{t-1}\right)+\sum_{i=1}^{l_{2}} \gamma_{i}(1+L) \hat{v}_{t-i}+\varepsilon_{t} \\
& \left(1+L^{2}\right) \hat{w}_{t}=\pi_{3}\left(-\hat{w}_{t-2}\right)+\pi_{4}\left(-\hat{w}_{t-1}\right)+\sum_{i=1}^{l_{3}} \gamma_{i}\left(1+L^{2}\right) \hat{w}_{t-i}+\varepsilon_{t}
\end{aligned}
$$

(Lof, 2001).

As seen here, the lagged dependent variables may be added to these auxiliary regressions given above. To detect the cointegration at the zero and semi-annual frequencies, $t$-statistic values of $\pi_{1}$ and $\pi_{2}$ should be compared to the critical values in the paper of Engle and Yoo (1987) and the null hypotheses of no cointegration at zero frequency and no cointegration at $1 / 2$ frequency should be tested for two auxiliary regressions in (6) and (7). On the other hand, for $1 / 4$ (and $3 / 4$ frequencies), $\mathrm{F}\left(\pi_{3}=\pi_{4}=0\right.$ ) test statistic value should be compared to the critical values which take place in the paper of Engle et al. (1993) and here the null hypothesis should be constructed as $H_{0}$ : No cointegration at $1 / 4$ (and $3 / 4$ ) frequencies for the third auxiliary regression given in (8) (Mert and Demir, 2014).

\section{Data Set and Application}

In this application, it has been aimed to investigate the existence of co-integration relationship between quarterly gross domestic product (GDP), final consumption expenditures of resident households (CONS), exports of goods and services (EXP), government final consumption expenditures (GOV) and private sector machinery-equipment (PRIEQ) series for the period 1998Q1-2014Q4. Data that are based on expenditure based GDP time series at fixed 1998 prices have been obtained from Central Bank of the Republic of Turkey (CBRT). First, in order to linearize the exponential growth in these series, their logarithms have been taken. Since by taking logarithm, variance is stabilized and the effects of outliers are reduced (Ture and Akdi, 2005).

In order to determine which series have a cointegrating relationship, it is necessary to find out at which frequencies series are integrated of the same order (or at which frequencies unit roots are present). For each series, three different models including "constant (C)", "constant+dummies (C,D)" and "constant+dummies+trend (C, D, T)" have been constructed. Also, the lagged values of the dependent variable have been added into these models. Since the series discussed are at quarterly frequency, seasonal unit root test results of the series at $\theta=0, \frac{1}{4}, \frac{1}{2}, \frac{3}{4}$ frequencies have been presented in Table 1. 


\begin{tabular}{|c|c|c|c|c|c|c|c|}
\hline Variables & $\begin{array}{r}\text { Auxiliary } \\
\text { Regressions }\end{array}$ & Lags & $t\left(\pi_{1}\right)$ & $t\left(\pi_{2}\right)$ & $t\left(\pi_{3}\right)$ & $t\left(\pi_{4}\right)$ & $\begin{array}{c}\mathrm{F} \\
\left(\pi_{3}, \pi_{4}\right)\end{array}$ \\
\hline \multirow[t]{4}{*}{ LNGDP } & Intercept & 2 & $-0.374639 *$ & $-1.658963 *$ & $-1.568273 *$ & $-1.650405^{*}$ & $2.681313 *$ \\
\hline & $\begin{array}{l}\text { Intercept }+ \\
\text { Dummies }\end{array}$ & 2 & $-0.352000 *$ & $-2.284324^{*}$ & $-2.049658 *$ & -2.370408 & $5.446632 *$ \\
\hline & Intercept & & & & & & \\
\hline & $\begin{array}{c}+ \\
\text { Dummies+ } \\
\text { Trend }\end{array}$ & 2 & $-2.528751^{*}$ & $-2.394737^{*}$ & $-1.809312 *$ & -2.278266 & $4.629866^{*}$ \\
\hline \multirow[t]{3}{*}{ LNCONS } & Intercept & 1 & $-1.108130^{*}$ & -2.087701 & -2.413501 & -1.715589 & 4.330118 \\
\hline & $\begin{array}{l}\text { Intercept + } \\
\text { Dummies }\end{array}$ & 2 & $-0.624776^{*}$ & $-2.256329 *$ & $-2.649649 *$ & -3.690152 & 12.64432 \\
\hline & $\begin{array}{c}\text { Intercept }+ \\
\text { Dummies }+ \\
\text { Trend } \\
\end{array}$ & 2 & $-2.329712^{*}$ & $-2.341915^{*}$ & $-2.498616^{*}$ & -3.514822 & 11.17496 \\
\hline \multirow[t]{4}{*}{ LNPRIEQ } & Intercept & 0 & $-1.048793 *$ & -3.006195 & -4.078979 & -6.309589 & 45.08480 \\
\hline & $\begin{array}{l}\text { Intercept }+ \\
\text { Dummies }\end{array}$ & 1 & $-1.255175^{*}$ & -4.758546 & $-2.938663 *$ & -5.416084 & 19.21220 \\
\hline & Intercept + & & & & & & \\
\hline & $\begin{array}{l}\text { Dummies } \\
+ \text { Trend }\end{array}$ & 0 & $-2.739185^{*}$ & -5.277844 & $-3.066718 *$ & -5.066384 & 23.55738 \\
\hline \multirow[t]{3}{*}{ LNGOV } & Intercept & 1 & $1.037847^{*}$ & $-0.672012 *$ & $-0.941324 *$ & $-0.406816^{*}$ & $0.522808 *$ \\
\hline & $\begin{array}{l}\text { Intercept }+ \\
\text { Dummies }\end{array}$ & 0 & $0.719595 *$ & -3.616989 & $-3.364203 *$ & $-0.412796^{*}$ & $5.776124 *$ \\
\hline & $\begin{array}{c}\text { Intercept }+ \\
\text { Dummies }+ \\
\text { Trend }\end{array}$ & 0 & $0.745482 *$ & $-0.608322 *$ & $0.013417 *$ & $-0.235981^{*}$ & $6.278467 *$ \\
\hline \multirow[t]{3}{*}{ LNEXP } & Intercept & 2 & $-1.033219 *$ & -2.208915 & $-1.552280 *$ & $-0.795612^{*}$ & $1.551227^{*}$ \\
\hline & $\begin{array}{l}\text { Intercept+ } \\
\text { Dummies }\end{array}$ & 0 & $-0.119803 *$ & -3.880223 & $-2.968691 *$ & -3.321427 & 12.04958 \\
\hline & $\begin{array}{c}\text { Intercept }+ \\
\text { Dummies }+ \\
\text { Trend }\end{array}$ & 2 & $-2.661086^{*}$ & -3.188178 & $-1.732976^{*}$ & -2.357943 & $4.688940 *$ \\
\hline \multicolumn{8}{|c|}{$\begin{array}{l}\text { Notes. }{ }^{1 *} \text { denotes insignificant values at } 5 \% \text { level. } \\
{ }^{2} t \text {-statistics for } \pi_{1} t\left(\pi_{1}\right) \text { shows whether there is a unit root or not at zero frequency }\left(H_{0}: \pi_{1}=0\right) \text {. t-statistics } \\
\text { for } \pi_{2} t\left(\pi_{2}\right) \text { tests the presence of the semi-annual unit root }\left(H_{0}: \pi_{2}=0\right) . F \text {-statistic for } \pi_{3} \cap \pi_{4}\left(F\left(\pi_{3}, \pi_{4}\right)\right) \text { tests } \\
\text { whether there is a unit root at quarterly frequency or not. } \\
{ }^{3} \text { Critical values have been taken from Hylleberg et al. (1990) for } N=100 \text { observations and } 5 \% \text { level. For zero } \\
\text { frequency, critical values are }-2.88,-2.95,-3.53 \text { and for semi-annual frequency, they are }-1.95,-2.94,-2.94 \text { respectively } \\
\text { for "intercept", "intercept }+ \text { dummies", "intercept }+ \text { dummies }+ \text { trend" models. }\end{array}$} \\
\hline
\end{tabular}

Table 1. HEGY Seasonal Unit Root Test Results for Quarterly Macroeconomic Series

In the application for seasonal unit root test, the appropriate lag length has been chosen in that way: Regression equation has been estimated first with Lag 1 and it has been investigated if first order and fourth order autocorrelations exist between residuals. For this investigation, it has been utilized from Lagrange Multiplier (LM) test statistics (thus for first order: $\operatorname{LM}(1)$ and for fourth order: $\operatorname{LM}(4)$ ). If any one of the null hypotheses of $H_{0}$ : There is no 1 st order autocorrelation and $H_{0}$ : There is no 4th order autocorrelation is rejected, lag length has been increased by one and LM test has been applied again. This process has been continued until the null hypothesis cannot be rejected for each order and homoscedastic residuals are obtained. LM(1) and LM(4) statistics results have been presented in Table 2: 


\begin{tabular}{|c|c|c|c|c|}
\hline VARIABLES & AUXILIARY REGRESSIONS & LAGS & $\mathrm{LM}(1)$ & $\mathrm{LM}(4)$ \\
\hline \multirow[t]{3}{*}{ LNGDP } & Intercept & 2 & $\begin{array}{l}2.285563 \\
(0.1306)\end{array}$ & $\begin{array}{l}8.015350 \\
(0.0910)\end{array}$ \\
\hline & Intercept + Dummies & 2 & $\begin{array}{l}0.728109 \\
(0.3935)\end{array}$ & $\begin{array}{c}4.011422 \\
(0.4045)\end{array}$ \\
\hline & $\begin{array}{c}\text { Intercept }+ \text { Dummies }+ \\
\text { Trend }\end{array}$ & 2 & $\begin{array}{l}0.018672 \\
(0.8913)\end{array}$ & $\begin{array}{l}5.215494 \\
(0.2659) \\
\end{array}$ \\
\hline \multirow[t]{3}{*}{ LNCONS } & Intercept & 1 & $\begin{array}{l}1.470532 \\
(0.2253)\end{array}$ & $\begin{array}{l}5.879280 \\
(0.2083)\end{array}$ \\
\hline & Intercept + Dummies & 2 & $\begin{array}{c}0.377129 \\
(0.5391)\end{array}$ & $\begin{array}{l}5.110070 \\
(0.2762)\end{array}$ \\
\hline & $\begin{array}{l}\text { Intercept }+ \text { Dummies }+ \\
\text { Trend }\end{array}$ & 2 & $\begin{array}{c}0.461174 \\
(0.4971)\end{array}$ & $\begin{array}{l}6.520621 \\
(0.1635)\end{array}$ \\
\hline \multirow[t]{3}{*}{ LNPRIEQ } & Intercept & 0 & $\begin{array}{c}0.130705 \\
(0.7177)\end{array}$ & $\begin{array}{l}8.780591 \\
(0.0668)\end{array}$ \\
\hline & Intercept + Dummies & 1 & $\begin{array}{c}0.468251 \\
(0.4938)\end{array}$ & $\begin{array}{l}1.220068 \\
(0.8748)\end{array}$ \\
\hline & $\begin{array}{c}\text { Intercept }+ \text { Dummies }+ \\
\text { Trend }\end{array}$ & 0 & $\begin{array}{r}0.693561 \\
(0.4050) \\
\end{array}$ & $\begin{array}{r}4.515437 \\
(0.3407) \\
\end{array}$ \\
\hline \multirow[t]{3}{*}{ LNGOV } & Intercept & 1 & $\begin{array}{c}0.364082 \\
(0.5462)\end{array}$ & $\begin{array}{c}4.615978 \\
(0.3290)\end{array}$ \\
\hline & Intercept + Dummies & 0 & $\begin{array}{c}0.798644 \\
(0.3715)\end{array}$ & $\begin{array}{c}2.349286 \\
(0.6718)\end{array}$ \\
\hline & $\begin{array}{c}\text { Intercept }+ \text { Dummies }+ \\
\text { Trend }\end{array}$ & 0 & $\begin{array}{l}0.294179 \\
(0.5876)\end{array}$ & $\begin{array}{l}1.192969 \\
(0.8793) \\
\end{array}$ \\
\hline \multirow[t]{3}{*}{ LNEXP } & Intercept & 2 & $\begin{array}{l}0.924163 \\
(0.3364)\end{array}$ & $\begin{array}{l}9.401415 \\
(0.0518)\end{array}$ \\
\hline & Intercept+Dummies & 0 & $\begin{array}{l}0.875675 \\
(0.3494)\end{array}$ & $\begin{array}{r}4.337515 \\
(0.3623)\end{array}$ \\
\hline & $\begin{array}{l}\text { Intercept }+ \text { Dummies }+ \\
\text { Trend }\end{array}$ & 2 & $\begin{array}{c}0.039849 \\
(0.8418)\end{array}$ & $\begin{array}{l}1.551871 \\
(0.8174)\end{array}$ \\
\hline
\end{tabular}

Table 2. LM(1) and LM(4) Statistics for Quarterly Macroeconomic Series

As it is clear from Table 2 that for selected lags, there are no first order and fourth order autocorrelation problems for all macroeconomic series.

If looked at the Table 1 results, it is seen that the presence of a unit root at zero frequency has been accepted for all variables in all three auxiliary regression models. When $\left.t\left(\pi_{1}\right), t_{(} \pi_{2}\right)$ and $\mathrm{F}\left(\pi_{3}, \pi_{4}\right)$ columns are examined, it is concluded that the null hypotheses that there is a (non-seasonal) unit root at zero frequency and there are seasonal unit roots at other seasonal frequencies cannot be rejected for three auxiliary regression models of LNGDP series at 5\% significance level. Thus, LNGDP series has a non-seasonal unit root at zero frequency and seasonal

unit roots at semi-annual ( $\frac{1}{2}$ frequency) and quarterly frequencies. While both LNCONS and LNPRIEQ series have the zero frequency unit root for three models with deterministic components given in Table 1, according to the results they both do not include any annual unit root (at quarterly frequency). For LNCONS series, the presence of semi-annual unit root has been accepted for two models except the "intercept" model. However, no semi-annual unit root has been detected in any model for LNPRIEQ series. When looked at the LNGOV and LNEXP series, both series are seen to include the zero frequency unit root. However, while LNGOV series has a seasonal unit root at semi-annual frequency for two models except the "intercept+dummies" model, LNEXP series rejects the presence of the semi-annual unit root for all three models. Finally, while LNGOV series has annual unit roots at

quarterly $\frac{1}{4}\left(\frac{3}{4}\right)$ frequencies for all deterministic models, LNEXP series has seasonal unit roots at quarterly frequencies for two models except only "intercept+dummies" model. In conclusion, cointegration relationship will be analyzed at frequencies in which these series are both integrated at the same order. In this case, it is necessary to determine which series are integrated of the same order at which frequencies. In all series, the presence of the zero frequency unit root has been detected in common. LNGDP, LNCONS and LNGOV series have been found to include seasonal unit root at semi-annual frequency. On the other hand, it has been determined that LNGDP, LNGOV and LNEXP series include seasonal unit roots at the quarterly frequencies $\frac{1}{4}\left(\frac{3}{4}\right)$. The results of seasonal cointegration analyses of the series at $0,1 / 2$ and $1 / 4$ (and $3 / 4$ ) frequencies have been presented in Table 3 , Table 4 and Table 5 respectively. 
In this application, regression models obtained from the linear components of the variables that are integrated at the same frequency have been estimated through OLS procedure. Before applying to cointegration analysis, it is necessary to give the transformations of variables that will be used in cointegration models. As a matter of example, it will be sufficient to present only LNGDP series (the other series will be transformed in the same way with LNGDP):

$$
\begin{aligned}
L N G D P_{1 t} & =\left(1+L+L^{2}+L^{3}\right) L N G D P \\
L N G D P_{2 t} & =-\left(1-L+L^{2}-L^{3}\right) L N G D P \\
L N G D P_{3 t} & =-\left(1-L^{2}\right) L N G D P \\
L N G D P_{4 t} & =\left(1-L^{4}\right) L N G D P
\end{aligned}
$$

Now let us mention about the cointegration models to be used. Seasonal cointegration has been mentioned in section 2.1. In addition, as also summarized by Ayvaz Kizılgöl (2011), in cointegration analysis the regression

\begin{tabular}{|c|c|c|c|c|c|c|}
\hline \multirow[b]{2}{*}{ Regressand } & \multicolumn{3}{|c|}{$\begin{array}{l}\text { Cointegration Analysis: } \\
\text { LGDP and LCONS }\end{array}$} & \multirow{2}{*}{$\begin{array}{c}\begin{array}{c}\text { Auxiliary } \\
\text { Regression }\end{array} \\
\text { Augmentation }\end{array}$} & \multicolumn{2}{|c|}{$\begin{array}{l}\text { Tests for Unit Roots } \\
\text { in Residuals }\end{array}$} \\
\hline & $\begin{array}{l}\text { Coefficient } \\
\text { Regressor } \\
\text { LGDP }_{1 \mathrm{t}}\end{array}$ & $\begin{array}{l}\text { Deterministic } \\
\text { Components } \\
\text { Included }\end{array}$ & $R^{2}$ & & DW & $\begin{array}{r}t \text { statistic } \\
t\left(\pi_{1}\right)\end{array}$ \\
\hline $\mathrm{LCONS}_{1 \mathrm{t}}$ & $\begin{array}{c}0.981403 \\
(80.95842)\end{array}$ & $\mathrm{C}$ & 0.990479 & $1,4,5$ & 1.998160 & -1.936136 \\
\hline $\operatorname{LCONS}_{1 t}$ & $\begin{array}{c}0.981366 \\
(79.04407)\end{array}$ & C, D & 0.990498 & 1 & 1.890828 & -2.615745 \\
\hline \multirow[t]{2}{*}{ LCONS $_{1 t}$} & $\begin{array}{c}1.006343 \\
(16.64040)\end{array}$ & $\mathrm{C}, \mathrm{D}, \mathrm{T}$ & 0.990526 & 1 & 1.892945 & -2.725444 \\
\hline & \multicolumn{3}{|c|}{$\begin{array}{l}\text { Cointegration Analysis: } \\
\text { LGDP and LPRIEQ }\end{array}$} & $\begin{array}{l}\text { Auxiliary } \\
\text { Regression }\end{array}$ & \multicolumn{2}{|c|}{$\begin{array}{l}\text { Tests for Unit Roots } \\
\text { in Residuals }\end{array}$} \\
\hline Regressand & $\begin{array}{c}\text { Coefficient } \\
\text { Regressor } \\
\text { LGDP }_{1 t} \\
\end{array}$ & $\begin{array}{c}\text { Deterministic } \\
\text { Components } \\
\text { Included } \\
\end{array}$ & $R^{2}$ & Augmentation & DW & $\begin{array}{c}t \text { statistic } \\
t\left(\pi_{1}\right)\end{array}$ \\
\hline LPRIEQ $_{1 t}$ & $\begin{array}{c}1.951163 \\
(21.48804)\end{array}$ & $\mathrm{C}$ & 0.879940 & $1,4,5$ & 2.139510 & -3.405938 \\
\hline LPRIEQ $_{1 t}$ & $\begin{array}{c}1.951973 \\
(20.98828)\end{array}$ & $\mathrm{C}, \mathrm{D}$ & 0.880156 & $1,2,4$ & 1.934590 & -1.932861 \\
\hline LPRIEQ $_{1 \mathrm{t}}$ & $\begin{array}{c}4.817088 \\
(19.58387) \\
\end{array}$ & $\mathrm{C}, \mathrm{D}, \mathrm{T}$ & 0.964776 & $1,4,5,8$ & 2.240764 & -2.182390 \\
\hline & \multicolumn{3}{|c|}{$\begin{array}{l}\text { Cointegration Analysis: } \\
\text { LGDP and LGOV }\end{array}$} & $\begin{array}{l}\text { Auxiliary } \\
\text { Regression }\end{array}$ & \multicolumn{2}{|c|}{$\begin{array}{l}\text { Tests for Unit Roots } \\
\text { in Residuals }\end{array}$} \\
\hline Regressand & $\begin{array}{c}\text { Coefficient } \\
\text { Regressor } \\
\text { LGDP }_{1 \mathrm{t}}\end{array}$ & $\begin{array}{c}\text { Deterministic } \\
\text { Components } \\
\text { Included } \\
\end{array}$ & $R^{2}$ & Augmentation & DW & $\begin{array}{c}t \text { statistic } \\
t\left(\pi_{1}\right)\end{array}$ \\
\hline $\operatorname{LGOV}_{1 t}$ & $\begin{array}{c}0.938623 \\
(32.05764)\end{array}$ & $\mathrm{C}$ & 0.942239 & $1,3,4$ & 1.969561 & -1.531071 \\
\hline LGOV $_{1 t}$ & $\begin{array}{c}0.938442 \\
(31.27638)\end{array}$ & $\mathrm{C}, \mathrm{D}$ & 0.942281 & 1,3 & 1.935207 & -2.273428 \\
\hline $\operatorname{LGOV}_{1 t}$ & $\begin{array}{c}0.096085 \\
(1.020667)\end{array}$ & $\mathrm{C}, \mathrm{D}, \mathrm{T}$ & 0.976126 & 1 & 1.998045 & -1.664541 \\
\hline
\end{tabular}
model to be estimated for all variables that are integrated of the same order at the zero frequency is $Y_{1 t}=\alpha_{1} Z_{1 t}+u_{t}$. The residuals $\left(u_{t}\right)$ obtained from this cointegration model will be used in order to estimate auxiliary regression model at the zero frequency.

Table 3. Cointegration Test Results at Zero (Long Run) Frequency 


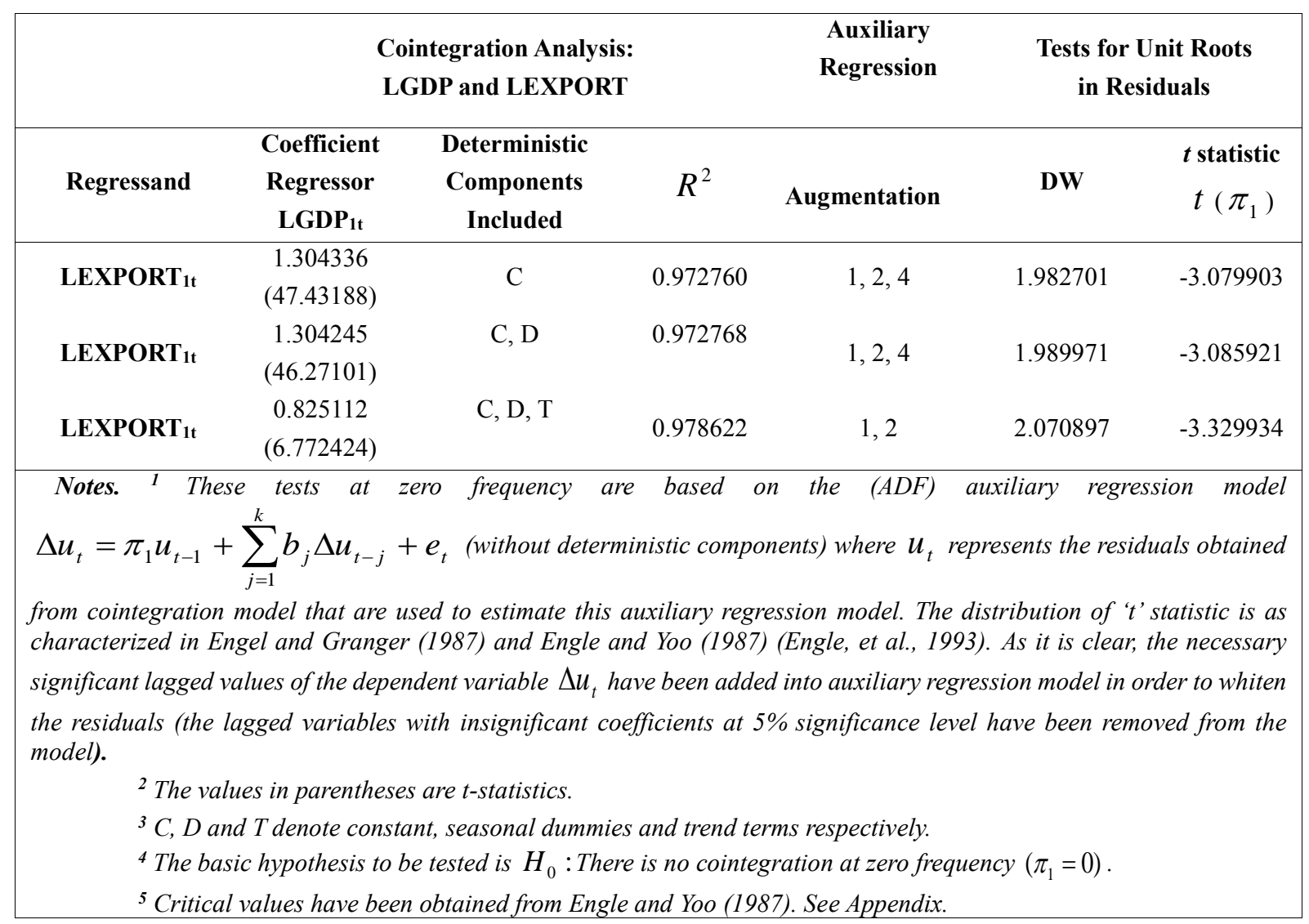

\section{Table 3 (Continued)}

For semi-annual $(1 / 2)$ frequency, the cointegration model to be used is $Y_{2 t}=\alpha_{2} Z_{2 t}+v_{t}$ and for quarterly frequencies, it is $Y_{3 t}=\beta_{1} Z_{3 t}+\beta_{2} Z_{3, t-1}+w_{t}$. Also, the residuals obtained from these models $\left(v_{t}\right.$ and $\left.w_{t}\right)$ will be used for estimating auxiliary regressions at specified frequencies respectively.

As mentioned before, in order to detect the long-run equilibrium relationship between the series, first of all it is necessary to determine the stationarity order of the series. In this application, for investigating the presence of seasonal cointegration relationship between the series, firstly seasonal unit root test has been applied in order to make inference about at which frequencies there are unit roots if they exist. The series discussed here have quarterly frequencies. Therefore, HEGY seasonal unit root test which is developed by Hylleberg et al. (1990) has been applied in order to detect seasonal unit roots and general results have been presented in Table 1 for three models with deterministic components that are "C", "C,D", "C,D, T". Now, Table 3 presents the cointegration test results at zero frequency. As a result, when cointegration test results are evaluated at the zero frequency, although the explanatory variables that take place in the cointegrating regression have been found to be statistically significant, no cointegrating relationship has been found between LNGDP and LNCONS, LNGDP and LNPRIEQ, LNGDP and LNGOV, LNGDP and LNEXP at 5\% significance level in the long-run. 


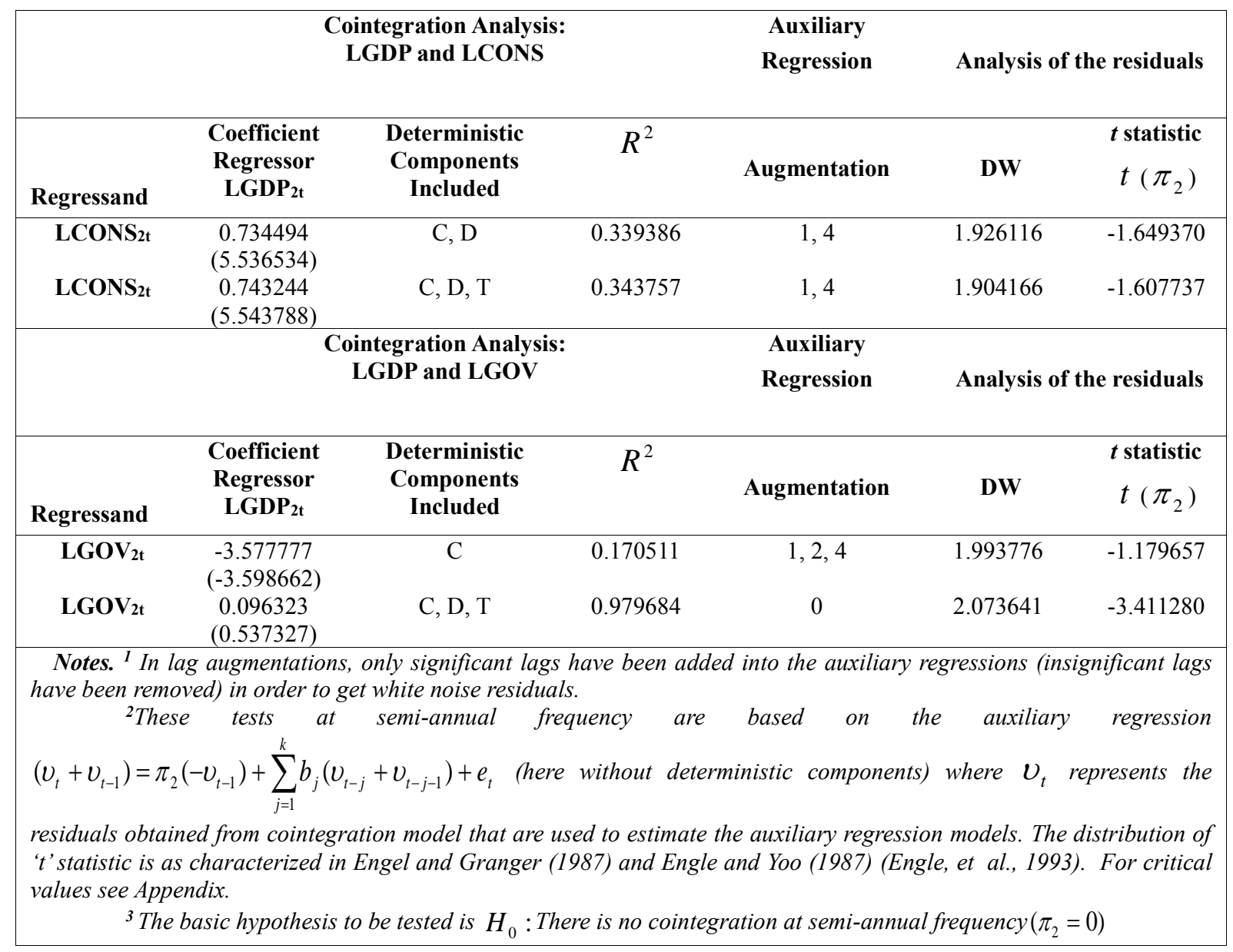

Table 4. Seasonal Cointegration Test Results at Semi-Annual (1/2) Frequency

LNGDP and LNCONS series have been found to be integrated of the same order for "C,D" and "C,D, T" models at $1 / 2$ frequency. Also, LNGDP and LNGOV series have been found to be integrated of the same order for "C" and "C,D,T" models at $1 / 2$ frequency. Therefore, cointegration analysis results at $1 / 2$ frequency have been shown in Table 4 for LNGDP, LNCONS and LNGOV series.

When Table 4 results are compared to the Engle and Yoo (1987) critical values for 5\% significance level, no cointegration relationship has been found between LNGDP \& LNCONS series and LNGDP \& LNGOV series at $1 / 2$ frequency. Thus, these series in interest do not seem to be cointegrated at the semi-annual frequency.

\begin{tabular}{|c|c|c|c|c|c|c|c|c|}
\hline \multirow{3}{*}{ Regressand } & \multicolumn{3}{|c|}{$\begin{array}{l}\text { Cointegration Analysis: } \\
\text { LGDP and LGOV }\end{array}$} & \multirow{3}{*}{\multicolumn{2}{|c|}{$\begin{array}{c}\begin{array}{c}\text { Auxiliary } \\
\text { Regression }\end{array} \\
\begin{array}{c}\text { Augmen- } \\
\text { tation }\end{array}\end{array}$}} & \multicolumn{3}{|c|}{$\begin{array}{l}\text { Analysis of the } \\
\text { residuals }\end{array}$} \\
\hline & \multicolumn{2}{|c|}{$\begin{array}{l}\text { Coefficient } \\
\text { Regressor }\end{array}$} & \multirow{2}{*}{$\begin{array}{l}\text { Deterministic } \\
\text { Components } \\
\text { Included }\end{array}$} & & & \multirow{2}{*}{$\begin{array}{c}t \text { statistic } \\
t\left(\pi_{3}\right)\end{array}$} & \multirow{2}{*}{$\begin{array}{c}t \text { statistic } \\
t\left(\pi_{4}\right)\end{array}$} & \multirow{2}{*}{$\begin{array}{c}F \\
\text { statistic } \\
\pi_{3} \cap \pi_{4}\end{array}$} \\
\hline & $\mathbf{L G D P}_{3 \mathrm{t}}$ & LGDP $_{3 t-1}$ & & & & & & \\
\hline $\mathrm{LGOV}_{3 \mathrm{t}}$ & $\begin{array}{l}0.786609 \\
(11.53730)\end{array}$ & $\begin{array}{l}0.903772 \\
(13.53999)\end{array}$ & $\mathrm{C}$ & 0.841278 & 1 & -2.712937 & -1.646483 & 5.045242 \\
\hline $\mathrm{LGOV}_{3 \mathrm{t}}$ & $\begin{array}{l}0.532680 \\
(4.450165)\end{array}$ & $\begin{array}{l}-0.182431 \\
(-1.536042)\end{array}$ & $\mathrm{C}, \mathrm{D}$ & 0.949005 & 1,2 & $-4.866891 *$ & 0.559515 & 12.19361* \\
\hline $\mathrm{LGOV}_{3 \mathrm{t}}$ & $\begin{array}{l}0.780067 \\
(11.52444)\end{array}$ & $\begin{array}{c}0.896061 \\
(13.55706)\end{array}$ & - & 0.839207 & 1,2 & -2.887014 & -1.199424 & 5.244342 \\
\hline
\end{tabular}

Table 5. Seasonal Cointegration Test Results at 1/4 (3/4) Frequencies 


\begin{tabular}{|c|c|c|c|c|c|c|c|c|}
\hline \multirow{3}{*}{ Regressand } & \multicolumn{4}{|c|}{$\begin{array}{l}\text { Cointegration Analysis: } \\
\text { LGDP and LEXPORT }\end{array}$} & \multirow{3}{*}{$\begin{array}{l}\begin{array}{l}\text { Auxiliary } \\
\text { Regression }\end{array} \\
\begin{array}{c}\text { Augmen- } \\
\text { tation }\end{array}\end{array}$} & \multicolumn{3}{|c|}{$\begin{array}{l}\text { Analysis of the Residuals } \\
\text { 'HEGY' test }\end{array}$} \\
\hline & \multicolumn{2}{|c|}{$\begin{array}{l}\text { Coefficient } \\
\text { Regressor }\end{array}$} & \multirow{2}{*}{$\begin{array}{l}\text { Deterministic } \\
\text { Components } \\
\text { Included }\end{array}$} & \multirow{2}{*}{$R^{2}$} & & \multirow{2}{*}{$\begin{array}{c}t \\
\text { statistic } \\
t\left(\pi_{3}\right)\end{array}$} & \multirow{2}{*}{$\begin{array}{c}t \\
\text { statistic } \\
t\left(\pi_{4}\right)\end{array}$} & \multirow{2}{*}{\begin{tabular}{l}
\multicolumn{1}{c}{$\boldsymbol{F}$} \\
statistic \\
$\pi_{3} \cap \pi_{4}$
\end{tabular}} \\
\hline & $\mathbf{L G D P}_{3 \mathrm{t}}$ & $\mathbf{L G D P}_{3 \mathrm{t}-1}$ & & & & & & \\
\hline LEXPORT $_{3 \mathrm{t}}$ & $\begin{array}{c}1.10825 \\
(21.79906)\end{array}$ & $\begin{array}{c}-0.007793 \\
(-0.156570)\end{array}$ & $\mathrm{C}$ & 0.884680 & $1,4,6,8$ & -2.497336 & -1.769538 & 5.254946 \\
\hline LEXPORT $_{3 t}$ & $\begin{array}{c}0.901760 \\
(5.869706)\end{array}$ & $\begin{array}{l}-0.073642 \\
(-0.483110)\end{array}$ & $\mathrm{C}, \mathrm{D}$ & 0.890232 & 1,4 & -2.542985 & $-2.241085 *$ & 5.692280 \\
\hline LEXPORT $_{3 \mathrm{t}}$ & $\begin{array}{c}1.111528 \\
(22.10056)\end{array}$ & $\begin{array}{c}-0.003930 \\
(-0.080016)\end{array}$ & - & 0.884001 & $1,4,5,6$ & -2.312909 & -1.327629 & 3.454144 \\
\hline $\begin{array}{c}\text { Notes. } \\
\left(w_{t}+w_{t-2}\right)=\end{array}$ & $\begin{array}{c}\text { These } \\
\tau_{3}\left(-w_{t-2}\right)+\end{array}$ & $\begin{array}{l}\text { ts at } \\
\left(-w_{t-1}\right)+\sum_{j=1}^{k}\end{array}$ & $\begin{array}{l}(\text { and } 3 / 4) \\
\left(w_{t-j}+w_{t-j-2}\right.\end{array}$ & $\begin{array}{l}\text { frequencies } \\
+e_{t} \quad \text { (here }\end{array}$ & $\begin{array}{c}\text { are based } \\
\text { without dete }\end{array}$ & $\begin{array}{l}\text { on the } \\
\text { erministic co }\end{array}$ & $\begin{array}{l}\text { auxiliary } \\
\text { nponents) }\end{array}$ & $\begin{array}{l}\text { regression } \\
\text { where } w_{t}\end{array}$ \\
\hline \multicolumn{9}{|c|}{$\begin{array}{l}\text { represents the residuals obtained from cointegration model that are used to estimate the auxiliary regression models (Engle, } \\
\text { et al., 1993). } \\
{ }^{2} \text { "C" denotes constant, " } D \text { " denotes seasonal dummies and "_- denotes no deterministic component. } \\
3 * \text { denotes significant values at } 5 \% \text { significance level. } \\
{ }^{4} \text { Critical values have been obtained from Engle et al. (1993). See Appendix for critical values. } \\
{ }^{5} \text { The basic hypothesis to be tested is } H_{0}: \text { There is no cointegration at } 1 / 4(\text { and } 3 / 4) \text { frequencies }\left(\pi_{3} \cap \pi_{4}=0\right) \text {. }\end{array}$} \\
\hline
\end{tabular}

\section{Table 5 (Continued)}

Table 5 presents seasonal cointegration test results at quarterly $1 / 4(3 / 4)$ frequencies. According to the Table 5 results, it can be said that there has been found a cointegration relationship between LNGDP and LNGOV series at quarterly frequencies $1 / 4$ (and $3 / 4$ ) for only the model with constant and seasonal dummies ("C,D"). In other saying, the null hypothesis saying that there is no cointegration at quarterly frequencies has been rejected with a significant joint $\mathrm{F}$ statistic of 12.19361. On the other hand, no cointegration relationship has been detected for no models between LNGDP and LNEXP series at $1 / 4$ (and $3 / 4$ ) frequencies.

\section{Conclusion}

In this paper, whether a cointegration relationship exists or not between quarterly GDP, CONS, EXP, GOV and PRIEQ series has been investigated. As a result of HEGY application, the presence of a zero frequency (nonseasonal) unit root has been detected for all series for the three models with "constant", "constant+dummies" and "constant+dummies+trend". LNGDP, LNCONS and LNGOV series have been found to include a seasonal unit root at semi-annual frequency. In addition, LNGDP, LNGOV and LNEXP series have been detected to have seasonal unit roots at quarterly $\frac{1}{4}\left(\frac{3}{4}\right)$ frequencies. It should be noted that cointegration analysis should be evaluated among the series having unit roots at the same frequency. When cointegration test results are evaluated thoroughly at the zero (long-run) frequency, there has been found no cointegrating relationship between LNGDP \& LNCONS, LNGDP \& LNPRIEQ, LNGDP \& LNGOV, LNGDP \& LNEXP at 5\% significance level. Similarly, no cointegrating relationship has been detected between LNGDP\&LNCONS series and LNGDP\&LNGOV series at semi-annual $(1 / 2)$ frequency. However, there has been found a cointegrating relationship between LNGDP \&

LNGOV series at quarterly $\frac{1}{4}\left(\frac{3}{4}\right)$ frequencies for only the model with "constant+dummies". On the other hand, no cointegrating relationship has been found between LNGDP \& LNEXP series for no models at these quarterly frequencies.

\section{References}

- Ayvaz Kızılgol, 2011. "Mevsimsel Eşbütünleşme Testi: Türkiye'nin Makroekonomik Verileriyle Bir Uygulama", Ataturk University - Journal of the Faculty of Economic and Administrative Sciences, 25, pp. 13-25.

- Caglayan, 2003. "Yaşam Boyu Sürekli Gelir Hipotezinde Mevsimsellik”, Marmara University, Journal of the Faculty of Economic and Administrative Sciences, 18, pp. 409-422.

- Chan and Wei, 1988. "Limiting Distributions of Least Squares Estimates of Unstable Autoegressive Processes”, Annals of Statistics, 16, pp. 367-401.

- Cubadda, 2001. "Complex Reduced Rank Models for Seasonally Cointegrated Time Series”, Oxford Bulletin of Economics and Statistics, 63, pp. 497-511. 
- Dickey, Hasza and Fuller; 1984. "Testing for Unit Roots in Seasonal Time Series", Journal of the American Statistical Association, 79, pp. 355-367.

- Engle and Granger, 1987. "Co-integration and Error Correction: Representation, Estimation and Testing”, Econometrica, 55, pp. 251-276.

- Engle and Yoo, 1987. "Forecasting and Testing in Co-Integrated Systems", Journal of Econometrics, 35, pp. 143-159.

- $\quad$ Engle, Granger and Hallman; 1989. "Merging Short and Long Run Forecasts: An Application of Seasonal Cointegration to Monthly Electricity Sales Forecasting”, Journal of Econometrics, 40, pp. 45-62.

- Engle, Granger, Hylleberg and Lee; 1993. "Seasonal Cointegration: The Japanese Consumption Function", Journal of Econometrics, 55, pp. 275-298.

- Granger, 1981. "Some Properties of Time Series Data and Their Use in Econometric Model Specification", Journal of Econometrics, 16, pp. 121-130.

- Granger, 1983. “Cointegrated Variables and Error Correction Models” (UCSD Discussion Paper 83-13a), University of California, San Diego.

- Granger and Weiss, 1983. "Time Series Analysis of Error-Correction Models”, in Samuel Karlin, Takeshi Amemiya and Leo A. Goodman (Eds.), Studies in Econometrics, Time Series and Multivariate Statistics, Academic Press, New York, pp. 255-278.

- Hamori and Tokihisa, 2001. "Seasonal Cointegration and the Money Demand Function: Some Evidence from Japan”, Applied Economics Letters, 8, pp. 305-310.

- Hylleberg, Engle, Granger and Yoo; 1990. “Seasonal Integration and Cointegration”, Journal of Econometrics, 44, pp. 215-238

- Johansen and Schaumburg, 1999. "Likelihood Analysis of Seasonal Cointegration”, Journal of Econometrics, 88, pp. 301-339.

- Kunst, 1993. "Seasonal Cointegration, Common Seasonals and Forecasting Seasonal Series", Empirical Economics, 18, pp. 761-776.

- Kunst and Franses, 1998. "The Impact of Seasonal Constants on Forecasting Seasonally Cointegrated Time Series", Journal of Forecasting, 17, pp. 109-124.

- Lee, 1992. "Maximum Likelihood Inference on Cointegration and Seasonal Cointegration", Journal of Econometrics, 54, pp. 1-47.

- Lof, 2001. On Seasonality and Cointegration, Ph. D. Dissertation, The Economic Research Institute Stockholm School of Economics, Elanders, Gotab.

- Lof and Lyhagen, 2002. "Forecasting Performance of Seasonal Cointegration Models", International Journal of Forecasting, 18, pp. 31-44.

- Maddala and Kim, 1998. Unit Roots, Cointegration and Structural Change, Cambridge University Press, Cambridge.

- $\quad$ Mert and Demir, 2014. "Mevsimsel Eşbütünleşme ve Mevsimsel Hata Düzeltme Modeli: İthalat - İhracat Verileri Üzerine Bir Uygulama", Suleyman Demirel University Journal of Faculty of Economics \& Administrative Sciences, 19, pp. 11-24.

- Sanli, 2015. The Econometric Analysis of Seasonal Time Series: Applications on Some Macroeconomic Variables, Master's Thesis, Cukurova University, Adana.

- Ture and Akdi, 2005. "Mevsimsel Kointegrasyon: Türkiye Verilerine Bir Uygulama”, Paper presented at the VII. National Econometrics and Statistics Symposium, 26-27 May, Istanbul University.

\section{Information Notes}

- This study has been derived from the Master Thesis that has been prepared in consultancy of Assoc. Prof. Mehmet Ozmen called "The Econometric Analysis of Seasonal Time Series: Applications on Some Macroeconomic Variables (Sanli, 2015)".

- This study has been supported by TUBITAK (The Scientific and Technological Research Council of Turkey) - BIDEB (Scientist Support Department) within the scope of 2211-E Direct National Scholarship Programme for PhD Students.

- This study has been supported by Cukurova University Rectorate - Department of Scientific Research Projects (BAP). 
Appendix: Critical Values for Seasonal Cointegration (for 100 observations)

\begin{tabular}{|cccc|}
\hline Number of Variables $(\mathrm{k}=5, \mathrm{~N}=100)$ & \multicolumn{3}{c|}{$\pi_{1}$ ve $\pi_{2}$} \\
\cline { 2 - 4 } Significance Level & $1 \%$ & $5 \%$ & $10 \%$ \\
\hline Critical Value & 5.18 & 4.58 & 4.26 \\
\hline
\end{tabular}

Table 6. Critical Values for Seasonal Cointegration at Zero and Semiannual Frequencies Source. Engle and Yoo, 1987.

\begin{tabular}{|cccccccccc|}
\hline $\mathrm{N}=100$ & \multicolumn{3}{c}{$\pi_{3}$} & \multicolumn{3}{c}{$\pi_{4}$} & & $\pi_{3} \cap \pi_{4}$ \\
\cline { 2 - 9 } $\begin{array}{c}\text { Deterministic } \\
\text { Component }\end{array}$ & $1 \%$ & $5 \%$ & $10 \%$ & $1 \%$ & $5 \%$ & $10 \%$ & $99 \%$ & $95 \%$ & $90 \%$ \\
\hline- & -3.94 & -3.30 & -3.00 & -3.01 & -2.12 & - & 10.24 & 7.21 & 5.91 \\
C & -3.86 & -3.27 & -2.95 & -2.95 & -2.08 & - & 10.15 & $\mathbf{7 . 1 0}$ & 5.83 \\
C, D & -4.77 & -4.12 & -3.81 & -3.02 & -2.14 & - & 13.26 & $\mathbf{1 0 . 1 2}$ & 8.66 \\
\hline
\end{tabular}

Table 7. Critical Values for Seasonal Cointegration at 1/4 (and 3/4) Quarterly Frequencies Source. Engle, et al., 1993. 